\title{
Increasing root penetration into a different environment is more important than improving rooting depth
}

\author{
Xue Gong ${ }^{1}$, Julian Taylor ${ }^{1}$, and Glenn McDonald ${ }^{1}$ \\ ${ }^{1}$ The University of Adelaide
}

June 12, 2021

\begin{abstract}
Deep rooting is often thought as a promising phenotype for resource extraction, but on soils with constraints, desired rooting depth was rarely observed. We hypothesised that if the genetic effect on root growth and rooting depth were separated from other effects, the determinants of root growth and rooting depth could be quantified. The conventional core-breaking method was used to measure root growth of wheat at two sites in two successive years under rain fed conditions. The Bayesian hierarchical nonlinear mixed models (HNLMMs) were employed to estimate root distribution, heritability and rooting depth. We found that root penetration from the non-sodic top to the sodic subsoil was most critical in determining rooting depth. Our study indicates that focusing on root-soil interaction at the transition layer where soil constraints start to emerge would lead to a more effective solution to develop resilient roots. Our work not only serves as a guide for selecting genotypes in pot trials, but also provides a theoretical support to breed advance crops with better soil adaptation.
\end{abstract}

\section{Hosted file}

Plant Cell Env - Manuscript.docx available at https://authorea.com/users/419391/articles/ 525908-increasing-root-penetration-into-a-different-environment-is-more-important-thanimproving-rooting-depth

\section{Hosted file}

Plant Cell Env - Figures.docx available at https://authorea.com/users/419391/articles/525908increasing-root-penetration-into-a-different-environment-is-more-important-thanimproving-rooting-depth 